\title{
Kan J A Heyns se Sosiale Etiek ons teologies toerus vir die toekoms*
}

\author{
A C J van Niekerk
}

\begin{abstract}
Can J A Heyns' Social Ethic equip us theologically for the future?

Heyns' socio-ethical model, which is based on a "cultivar" of the Calvinistic philosophy, provides ethical stability with it's theocentric anchor. However, it shows shortcomings as to flexibility and relevancy because a dialectic between deductive and inductive ways of theologizing is lacking. The use of the notion "Volksverband" (national bond) as an ethical pillar in the first chapter cannot be derived from a New Testamentical centre but can rather be connected to the theology of creational orders. Although the chapter contains important ethical directives for internal dialogue amongst (white) Afrikaners, there is very little on the economic, semiotic, restitutional and ecological facets of modern group-forming tendencies. Heyns' ethics on the State (the second chapter of the book) contains valuable facets among which we find an aversion to modern warfare. Unfortunately the main premise is based on inadequate exegesis of Romans 13. In the last chapter on the Church, Heyns proves himself to be an ecumenical and renovating thinker concerning the ethical task of the Church.
\end{abstract}

Inleiding

Om te beweer dat Suid-Afrika voor uitdagende sosiaal-etiese probleme te staan gekom het, het 'n cliché geword. Die frekwensie van die stelling verander geensins aan die erns van 'n omvattende oorgangstadium wat op byna alle terreine van ons samelewing ondervind word nie. Afrikaner-Christene sal hierin moet meewerk terwyl hulle boonop vir die (myns insiens onregverdige) oormaat van skuld wat weens apartheid aan hul opgele is, verantwoording moet doen. Die lidmate van die Ned Geref Kerk se Christelike sosiaal-etiese bydrae moet dus van so 'n standaard wees dat dit nie alleen 'n sinvolle bydrae lewer nie, maar ook geloofwaardigheid terugwen.

Dit is in hierdie situasie wat Heyns se derde boek oor die Teologiese Etiek verskyn het. Die band $(2 / 2)$ handel oor die samelewingsverbande volk, staat en kerk (in die doelbewuste volgorde). Dit is geskryf tydens die beroeringe in die laaste helfte van die vorige dekade en verskaf aan studente, predikante en indirek aan lidmate 'n uitgebreide gereformeerde denkraamwerk oor die verskillende lewensverbande. Die sentrale vraag is of die derde band in 'n genoegsame mate predikante en lidmate sal toerus om in die volgende dekade 'n sinvolle en geloofwaardige bydrae tot samelewingshervorming te kan lewer. * 'n Resensie-artikel oor J A Heyns se Teologiese Etiek 2/2: Sosiale Etiek, N
G Kerkboekhandel, Pretoria 1989. 
Om 'n gevorderde denker van die formaat van Heyns se produk krities te ontleed en aan die vermeende eise van die toekoms te toets, is geen geringe taak nie. Dit kan selfs as arrogant beskou word. Dit moet eerder beskou word as die soekende vrae van 'n oudstudent aan sy gerespekteerde mentor. As "junior vennoot", om Heyns se eie terminologie te gebruik, het ek immers in 'n ander tydruimtelike konteks grootgeword. Dit was in die tyd toe die Afrikaner se ekonomiese-, politieke- en taalstryd reeds verby was. Dit was ook die tyd toe swart nasionale bewegings tot uitbarsting gekom het in byvoorbeeld die Soweto-onluste van 1976. Nuwe eksegetiese metodes was aan die orde van die dag en die historieskritiese benadering het 'n groot invloed uitgeoefen op die hermeneutiek en ook die ander geesteswetenskappe. Hierdie resensie is immers in 1991 - meer spesifiek ná 2 Februarie 1990 geskryf - wat die resensent ten koste van die skrywer bevoordeel. Al sou die opmerkings wat hier volg alleen maar die veranderde denksituasie reflekteer, dan dien dit alreeds 'n doel.

In hierdie resensie-artikel sal ek eerstens opmerkings maak oor die samestelling van die boek voordat ek die drie hoofstukke in volgorde sal bespreek. Deurgaans sal ek sowel 'n kort opsomming of uittreksel van die werk weergee, as om daarop enkele vrae te vra. Met die endnotas sal ek poog om Heyns se boek met ander etiese werke in verband te bring.

1 Samestelling van die boek - gevul met etiese koninkryksbeginsels maar waar is die relevante eindpunte?

Met hierdie werk betoon Heyns hom weer as 'n uitstaande klassifikus. Klassifikasie van begrippe, uiteensettings van wesenskenmerke, detailonderskeidings en daaruit geformuleerde definisies neem die meeste ruimte in beslag. Dit vorm 'n bostruktuur van beginsels waaruit sosiaal-etiese riglyne op deduktiewe wyse getrek word. Die beginsels is met Bybelse teksverwysings aan 'n teologiese sentrum, die Koninkryk van God, verbind.

Sosiale analises, die werking van beginsels in verhouding met ideële en materiële belange, en die allesdeurdringende verskynsel van mag word nie met die hulp van geesteswetenskaplike modelle verklaar en benut nie. Dit beteken nie dat Heyns sonder 'n model werk nie. Die Calvinistiese wysbegeerte van onder andere Stoker (Skeppingsidee) en Dooyeweerdt (Wetsidee), wat Heyns meesterlik uitbou (Koninkryksidee), dien as sleutel waarmee die werklikheid en Bybelse tekste en begrippe ontsluit word.

Hierdie etiese benadering, wat as ' $n$ vorm van deontologie bestempel kan word, het sekerlik voordele. Dit verskaf stabiliteit aan 'n etiese model, 'n eienskap wat in ons tyd veral van groot belang is vir die welsyn van 'n samelewing.

Die boek getuig dan ook van 'n deur God aangegrypde denker wat nie skroom om sy denke teosentries te veranker nie. Heyns neem sterk standpunt in teen relativistiese tendense en denke vanuit 'n geslote werklikheidsbeskouing'.

Ook die gepaardgaande idealistiese trekke het 'n voordeel. Die stel van positiewe ideale is vir opbouende aktiwiteite nodig. Weinig kan bereik word sonder 'n goeie plan of ontwerp. Die mens wat keuses moet maak, moet volgens Moltmann met positiewe planne gehelp word om 'n opbouende keuse te maak. Moltmann self stel 'n messiaanse etiek as ' $n$ ideaal om daardeur geweldlose handeling en vrede in die wêreld te bewerk². 
Die nadele van Heyns se metode om definisies as normatiewe te stel is dat dit selfkritiese en buigsame denke beperk. Van die koninkryksideale wat Heyns stel, sal utopisties en groepsugtig geïnterpreteer kan word omdat nie met die belange van alle mense in die huidige werklikheid geïdentifiseer is nie. Dit wat ons as ideale en beginsels stel, bevat gewoonlik alreeds net ons eie beperkte belange. Die teorieë wat ons op deduktiewe wyse op die praktyk wil toepas is in werklikheid reeds deur ons eie lewenspraxis beïnvloed. Denke is immers kontekstueel verankerd. Selfs al sou mens die leer van die comptio totalis afwater, sou ons nie kan ontken dat wat ons as goddelike beginsels stel, alreeds deur ons as sondige mense geinterpreteer is nie. Teologiese denke is en bly menslike produkte. Soos die menslike samelewing die produk is van 'n ondeursigtige korrelasie van ideële, materiële en sosiale kragte word die menslike denke ook daardeur aangedryf. Dit is realisties en eerlik om die hamartiologiese perspektief in menslike denke te erken. Dit lyk my daarom belangrik dat die insigte van die kennissosiologie dat alle denke en argumentasie vanuit 'n spesifieke sosiale en historiese raamwerk gedoen word, doelbewus in etisering in aanmerking moet kom ${ }^{3}$.

'n Deontologiese benadering wat idealisties ingestel is vind dit verder ook moeilik om relevant te wees. Die deduktiewe weg van denke geskied ten koste van die induktiewe weg en van die dialektiek tussen die weë kom min tereg. Dit verskaf wel stabiliteit, maar nie genoegsame buigsaamheid nie. In die verband kan ek aan enkele leemtes dink wat die samestelling van die boek betref4.

- Deur nie die problematiek van volk, staat en kerk binne die internasionale konflikte van Suid versus Noord, Oos versus Wes te plaas nie, het Heyns wel die problematiek van situasie-analise grootliks vermy. Die vraag is net of enige etiese werk in die Suider-Afrika substreek (of elders!) geskryf kan word sonder om dit in die breë wêreldkonteks te verklaar. Kan kinders se rusies verstaan word sonder om die ouers se egskeiding deeglik in ag te neem?

- Predikante word dikwels deur lidmate en ander persone gekonfronteer met "Dit is ekonomiese realiteite"-argumente. Die debat tussen ekonomiese belange versus etiese beginsels is nie net in die arbeidsituasie nie (vgl Teologiese Etiek $2 / 1$, maar ook in die konflikte tussen volke, en sowel in die interne problematiek van die staatshuishouding as in die ekumeniese debatte op die prioriteitslys. Predikante moet nie net aan die 18e eeuse ideologiese stryde (al die ismes) en die nasionale oorloë en politieke revolusies van $20 \mathrm{e}$ en $21 \mathrm{e}$ eeu georiënteer word nie. Die toenemende ekonomiese oorlewingstryd gaan waarskynlik die sentrale probleem van die (oor minder as 9 jaar) 21 e eeu wees. Ek vind te min van hierdie bewustheid in Teologiese Etiek 2/2.

* Heyns se beskrywing van die moderne lewens- en wêreldbeskouing (byvoorbeeld eksplisiet op p390-399) is net negatief en beperk tot die a-godsdienstigheid en die geslote wêreldbeeld. Daar is al hoe meer tendense dat die postmoderne tyd - met sy herevaluering van wetenskap en tegniek, die hersiening van die positivistiese werklikheidsredusering ten gunste van 'n meer holistiese benadering en selfs die herwaardering van die transendente en die mistieke nuwe uitdagings aan godsdienste en veral die Christendom bied. 
* Nog 'n belangrike debat wat aangespreek sal moet word is die persoonsbehartiging van die vrou in die samelewingsverbande. Heyns skryf wel verhelderend daaroor in Teologiese Etiek 2/1. In hierdie werk erken hy alleen op terloopse wyse seksisme as eties afkeurende diskriminasie (p47), sê dat antiseksisme 'n doelwit van burgerlike ongehoorsaamheid is ( $p 167)$, en pleit in een sin vir die vrou in die amp (p325). Dit blyk so 'n belangrike saak in volk, staat en kerk te wees dat eksplisiete behandeling nodig is.

* Ten slotte: Die grootste leemte in die samestelling van die boek is dat normering nie opgevolg word met 'n duidelike kontekstualisering nie. Deur beginsels te stel, maar te huiwer om norme deurgaans te konkretiseer, kan gevra word of dit nie 'n ernstige verskraling van die kerk se taak is nie. As die kerk die openbaring nie mag "vermink" nie, maar oor menseregte, medemenslike verhoudinge, volks- en nasiebeskouing relevant moet wees (p342), maar tog nie die Bybelse beginsels mag "uitwerk" en "konkretiseer" nie (p343), is dit problematies. Die onderskeid dat die kerk nie "terreinbeperk" is nie, maar wel "taakbeperk" (p326), beteken tog dat tersake konkretisering sal moet plaasvind. Die instituut-lidmaat onderskeiding bevredig ook nie weens die afwesigheid van prinsipiële motiveringe vir so 'n skerp onderskeid.

Die vraag tot dusver was of die uitgebreide klassifikasiesisteem wat Heyns bied optimaal bydra tot 'n verwysingsraamwerk waarmee nuwe morele probleme aangepak sal kan word. Vervolgens bespreek ek spesifieke sake soos dit in Teologiese Etiek 2/2 se drie hoofstukke na vore kom.

"Volksverband" - 'n te smal sambreel?

Heyns beskryf ses samelewingsverbande waarbinne die mens se sosiaal-etiese lewe voltrek word. Met sy keuse van huwelik, gesin, kultuur, volk, staat en kerk volg Heyns die tradisionele indeling van ordeninge wat aan die Voorsienigheid of Skepping van God verbind is. By Emil Brunner bestaan die ordeninge uit die gemeenskap van huwelik en familie, die gemeenskap van arbeid, die gemeenskap van volk en die staat, die gemeenskap van kultuur en die gemeenskap van geloofs. Brunner het die Duitse ordeningsteologie probeer suiwer deur te erken dat die skeppingsordinansies se historiese vorm menslik, sondig en goddeloos kan wees en gevolglik aan Christus se gebod onderworpe moet word. Volk as skeppings- en voorsienigheidsordening is egter weens die Duitse misbruik, die Nuwe-Testamentiese relativering van volkere en die evolusionistiese proses waaraan volkere onderwerp is by meeste etici, wat die ordeningsteologie op een of ander wyse behou het, weggelaat 6 . Dietrich Bonhoeffer handhaaf byvoorbeeld net vier "mandate" van God in die wêreld, naamlik arbeid, huwelik, owerheid en kerk, en al vier word sterk Christologies ingeklee?.

'n Ernstiger vraag is of die noemer "volksverband" hoegenaamd soveel aandag moet ontvang in 'n Etiek wat die Nuwe Testament as kroongetuie oor God se Wil moet eerbiedig?

Heyns meen in dié hoofstuk dat die bestaan van volke, rasse en nasies nie geïgnoreer kan word nie. Die blote bestaan van werklikhede legitimeer egter nie dié van volk as 'n etiese pilaar van die Christendom nie. 
Die saak oor die volk word verder geregverdig deur 'n woord-onderskeiding eerder as deur die Woord. Volksliefde (nasionalisme in 'n enger sin) is vir Heyns "beslis eties aanvaarbaar" omdat selfliefde en naasteliefde mekaar nie uitsluit nie en omdat nasionalisme gehoorsaam is aan God en sy Woord en diensbaar is teenoor alle mense (p23; herhaal in ander formuleringe op p43, p66, p143 en p327). Met hierdie formuleringe word die relativering van die volk as samelewingsgrootheid, soos dit in die Nuwe Testament, maar ook in die verhale van Jona en Rut na vore kom, nie mee rekening gehou nie. Waarskynlik is die beklemtoning van volk deels veroorsaak deur die Calvinistiese filosofie se neiging om totalitêr te wees. Gevolglik word die Nuwe-Testamentiese onderskikking van volk en staat aan kerk en koninkryk vervang met 'n neweskikking van hierdie maatskaplike verbande.

"Ras" word wel op aanvaarbare gronde as 'n biologiese, "volk" as kulturele en "nasie" as politiekstaatkundige begrippe deur Heyns afgegrens. Verder word dit as dinamiese groothede wat kan en mag verander, beskou (p4-5). Terwyl 'n meganiese volksbegrip van die liberalisme (nivellering van die volk) en die totalitaristiese volksbegrip van die "nasionalisisme" (verabsolutering van die volkvgl p35) tereg afgewys word, word 'n organiese volksbegrip gekies wat gekenmerk word deur gemeenskaplike bloed-, kultuur-, etos-, geskiedenis-, bodem- en solidariteitsband (p13-20).

Die sosiaal-etiese implikasies van Heyns se volksliefde beginsel ten opsigte van die houding teenoor die "eie" is onder andere dat Christelike en volkseie onderwys voorgestel word. Daarby maak die "feitlike situasie in Suid-Afrika", onderwys wat op die nasionale gerig is, nodig (p27-28). Ten opsigte van die houding teenoor die "ander" word die sosiaal-etiese implikasies op die temas diensbaarheid, voogdyskap, diskriminasie en apartheid toegepas.

Daar is ongetwyfeld heelwat van die stof wat Afrikaner-predikante goed kan toerus vir die komende dekade. Om enkele voorbeelde te gee:

- Die steeds bestaande rasionaal vir rassisme deur biologiese-genetiese meerderwaardigheid word gekelder deurdat kulturele verskille aan historiese oorsake verbind word (p38-39).

- Diskriminasie is sosiaal-eties onaanvaarbaar omdat dit in teenstelling met differensiasie mense ongelyk behandel weens "nie ter sake" verskille. Skade word berokken aan die ontvangers en uitvoerders van diskriminasie. Diskriminasie in wetgewing (bv apartheidswette) is totaal onaanvaarbaar (p46-47,67).

- Apartheid het polities-staatkundig misluk weens ekonomiese realiteite (p49).

- Die negatiewe kontaksituasie tussen Europeërs en slawe het aanleiding gegee tot stereotiperinge ten opsigte van ras wat "sosiaal-psigologies" begryplik is, maar weens die "dinamiese ontwikkelingspotensiaal van die menslike persoon" nie "sosiaal-eties" verdedigbaar is nie $(p 66,68)$.

- Die Ned Geref Kerk het beslis bygedra tot die inwerkingstelling van legalistiese apartheid (p98-102).

Ten slotte: 'n waardevolle hoofstuk vir predikante wat onder Afrikaners werk. Die 
voordeel dat dit oor teenwoordige aktuele probleme handel - byvoorbeeld daar word "tans" oor diskriminerende apartheidswetgewing gehandel (p58) - beteken ongelukkig ook dat dit oor 'n relatiewe kort periode as geskiedenis hanteer sal word. Die nadeel dat moderne groepvorming soos sub-kulture, binnelandse ekonomiese drukgroepe en trans-kulturele groepe nie bespreek is nie, is duidelik in die lig van byvoorbeeld die ambivalente groepvormingstendense in Europa. In Wes-Europa word 'n holistiese Europese burgerskap nagejaag terwyl nasionalistiese groepvorming in Oos-Europa hoogty voer. Die gemene faktor is waarskynlik ekonomiese realiteite. Vir hierdie faktore, wat so 'n groot rol speel in kollektiewe persoonsverhoudinge, is die noemer "volksverband" heeltemal te smal.

Heyns se grondliggende en konsekwent deurlopende beginsel is dat die staat 'n voorsienigheidsverordening van God is. Dit beteken dat die staat die swaard met verantwoordelikheid moet hanteer en selfs dat die staat wat die swaard nie meer wil hanteer nie, nie langer staat is nie $(p 117,129,132,133)$. Verder beteken dit dat die doodstraf ' $n$ "reg" en 'n "plig" is (p162); dat die reg van militêre diensplig goddelik gesanksioneer word (p178); dat die owerheid so teen terroriste moet optree dat hy sy goddelike roeping nie moet verloën nie (p206); en dat revolusie veroorsaak word omdat daar geen ontsag meer vir (Goddelike) gesag is nie (p216). 'n Staat mag nie 'n anti-militaristiese filosofie huldig of verdedig nie. Wanneer die staat sy reg om oorlog te maak laat vaar kom dit neer op wêreldontvlugting, verraad teenoor sy burgers en roepingversaking teenoor God (p229-230).

Vir hierdie sterk beginsel en uitsprake steun Heyns alleen op Romeine 13, hoewel ook ander tekste genoem word (p116-117). Die interessante teenstrydigheid van Bybeltradisies rakende Israel se koningskap word nie genoem nie. Wel word Romeine 13 teenoor Openbaring 13 gestel. Die spanning word nie deurgaans as teologiese raamwerk eerbiedig nie. Die tema word eerder aan 'n soort teokratiese realiteit as aan die "teo-antropologiese realiteit" (p119) en die moontlikheid van demoniese verwording verbind. Met die verbinding van Paulus se verwysing in Romeine 13 aan die koninkryk van God word daar besin oor 'n "Christelike staat", en in hoofstuk 11 word selfs gese dat die staat 'n "amp" in die koninkryk van God is (p335).

Die vraag of Paulus se Goddelike ordening van die staat, wat aansluit by die antieke tyd se behoefte om die staat goddelik te sanksioneer, sinvol as ' $n$ beginsel op die moderne demokratiese tyd toegepas kan word, word nie deur Heyns oorweeg nie. Dit bring die Bybelse begronding van Heyns se filosofiese struktuur oor die staat in die gedrang. Die "beginsel" wat uit die tendensgeskrif van Paulus kom, is immers dat Christene hulle nie aan aardse realiteite moet onttrek nie, maar eerder in liefde - selfs onder heidense owerhede - betrokke moet bly!

In die beskrywing van die temas gesag, reg, mag en funksie-grense van die staat en ook oor die verhouding staat en politiek word waardevolle riglyne gegee. So byvoorbeeld is verskillende volke binne een staat aanvaarbaar ( $p 125,143$ ). Christelike politiek is toekomsgerig om maksimum geregtigheid te bereik, dit is konserwatief en progressief tegelyk (p147). Christene in die politiek hoef nie noodwendig Christelike politieke partye te vorm nie (p149).

Wat die staatlike konflik-etiek betref word sulke belangrike temas 
behandel dat dit vervolgens afsonderlik bespreek sal word.

\subsection{Straf}

Die reg van die staat om te straf word streng gehandhaaf, maar met bepaalde voorwaardes, wat insluit dat die staat self sorg moet dra om nie skuldig te wees aan geïntitusionaliseerde onreg nie (p153); dat die doel van straf verbetering en voorkoming moet wees (p152, 155-157); en dat vorme van straf soos foltering (sluit dit eensame aanhouding in?), maar ook geen vergelding van misdadigers, onaanvaarbaar is ( $\mathrm{p} 154-155)$.

Die reg van die staat om die doodstraf op te lê, word prinsipieel erken omdat die hoogste waarde nie menslike lewe is nie. Volgens die skrywer is daar nie Bybelse gegewens daarteen nie. Dit is jammer dat die skrywer hierin op ' $n$ fundamentalistiese wyse omgaan met tekste en die Voorsienigheidswoord wat elders so goed te pas kom, nie hier ter sprake bring nie. Doodstraf word prinsipieel nie teengestaan nie, maar alleen vanweë die frekwensie daarvan word op "religieusetiese gronde" gewaarsku teen 'n "doodstraf fanatisme". Die spesifieke "religieusetiese" gronde of alternatiewe vir doodstraf word nie bespreek nie (p157-162, 249).

\subsection{Militêre diensplig}

Oor militêre dienspligweiering handhaaf Heyns enersyds die reg van die staat om burgers tot militêre diensplig op te roep "... die plig van die owerheid, van Godsweë, om die land te verdedig en dus mense in opdrag dood te maak. Die owerheid kan homself nie van sy verantwoordelikheid onthef nie, aangesien hy dit nie aan homself opgedra het nie" (p181-182). Heyns handhaaf andersyds ook die gewetensoordeel van die enkeling, maar waarsku teen vrydenkery en vereis dat die gewetensoordeel getoets moet word aan God se Voorsienigheidswoord en ook sy Skrifgeworde Woord.

Dat hier, soos elders, belangrike onderskeidinge en goeie insigte deurgegee word, is duidelik. Die spanning tussen individuele gewetensoordeel en die owerheidsverantwoordelikheid is sekerlik die kern van hierdie etiese problematiek.

Heyns los die konflik ten opsigte van totale pasifisme op deur te beweer dat voorskrifte van 'n goddelike Opperwese swaarder moet weeg as gehoorsaamheid aan die staat. Die staat behoort vir totale pasifiste alternatiewe gemeenskapsdiens te laat doen. In geval van selektiewe passifisme sou daar nie die "voorrang van opdragte van 'n Opperwese" bo die van staat wees nie en vir die "subjektiewe" oorwegings kan die toegewings nie gemaak word nie. Hieroor enkele vrae:

(i) Die "teoretiese duidelike onderskeid" tussen geloofspolitiek-, gewetensen persoonlike besware (p179 ev) is vir my nie bevredigend nie. Heyns erken wel dat daar "praktiese oorvleueling" bestaan (p186-187), maar tog word die sleutel-oplossing gekoppel aan die moontlikheid om subjektiewe besware van geloofsbesware te skei. Vir Calviniste moet al hul (subjektiewe) keuses tog geloofskeuses wees! Lutherane sal ook probleme daarmee hê omdat 'n besluit oor militêre dienspligweiering op die vlak van gesonde verstand lê en nie op die vlak van goddelike openbaring besilis kan word nie. 
(ii) Deur nie die inhoudelikheid van politieke besware te weeg nie, maar alleen na die formele aspek dat verskille met 'n politieke beleid nie rede is vir dienspligweiering nie, te verwys (p182) word geloofsgehoorsaamheid 'n a-historiese saak waarin die Voorsienigheidswoord nie 'n rol het nie. Alleen totale passifiste het reg. Maar kan selektiewe passifiste nie sterk genoeg godsdienstige oortuigings hê nie? Kan politieke besware teen 'n oorlog (byvoorbeeld 'n burgeroorlog) nie van so 'n aard wees dat dit die land nie meer kan dien nie en so die bedoeling van militêre diensplig weerlê nie? Die hele vraagstuk van die legitimiteit van 'n owerheid kan hier nie vermy word nie.

(iii) Die aard van oorlogvoering waarvoor militêre dienspligtiges gebruik word, is ook van belang in die beoordeling van selektiewe passifisme. Benewens burgeroorlog wat die legitimiteit van die staat ernstig onder verdenking kan bring, is daar oorlogvoering met ABC-wapens. Laasgenoemde word opsigself deur Heyns eties afgekeur. Ons sou dit tog nie eties afkeur as 'n soldaat van Saddam Hoesein wat teoreties aan die Jihad glo, weier om in 'n imperialistiese oorlog chemiese wapens te gebruik nie?

Die riglyne oor dienspligweiering en ook die waarde van individuele vryheid is nie genoegsaam om of as 'n universele of as kontekstuele riglyn te dien nie.

\subsection{Terrorisme as gestalte van gewelddadige protes}

Terrorisme word as 'n kommunikasie-strategie verklaar: "Terrorisme soek nie net kommunikasie, maar terrorisme is kommunikasie" (p203). As algemene oorsaak van terrorisme word geïnstitusionaliseerde onreg wat 'n "administrasie van terreur" volg erken, maar die kommunikasie van onregsimbole as spesifieke problematiek word nie bespreek nie. Die semiotiek kan hier handige en opwindende perspektiewe vir die Christelik-sosiale konflik-etiek bied8.

In die relatief kort etiese riglyne vir kontra-terroristiese optrede gee Heyns die verwydering van staatlike onreg en terreur as algemene riglyn weer en daar word nie spesifiek na kommunikasie van owerheids- en nasionale simbole verwys nie. 'n Endnota meld dat die staat sensuur kan toepas om terrorisme te bestry (p272), maar die morele implikasies en moontlik kontra-produktiewe reaksies word nie bespreek nie.

Dit is jammer dat daar in teenstelling met die toepassing in die SuidAfrikaanse situasie van die bespreking van byvoorbeeld diskriminasie en Swart Teologie hier nie deurgedring word na die Suid-Afrikaanse terroriste problematiek rakende byvoorbeeld doodstraf vir terroriste, sielkundige oorlogvoering, Koevoet, die BSB en ander teeninsurgensie optredes, aanhouding sonder verhoor en huis tot huis klopjagte in swart woonbuurtes nie. 'n Gebalanseerde mening, wat by uitstek deur Heyns gegee kan word, het ons baie nodig. 'n Enkele endnota meld dat aanhouding sonder verhoor kontra-produktief in Noord-Ierland was (p272-273). Dit kan aanvaar word dat die soort probleme in 'n pluralisties en gepolariseerde SuidAfrika, lank na die aanvaarding van 'n breë politieke oplossing, steeds lewensbelangrike aandag sal verg. 
Die begrip "revolusie" word deur Heyns afgegrens teen evolusie, mutasie, reformasie, transformasie en restourasie (p208-209). Inhoudelik word dit vergelyk tussen 'n neo-Marxistiese verstaan van revolusie en reformasiedenke. Laasgenoemde se ideale word goed verwoord as ' $n$ uitnemender weg vir verandering, maar die onvermoë of suksesse van reformatoriese denke om toestande van revolusie uit te skakel word nie bespreek nie. Die Marxistiese beskuldiging dat onregverdige magshebbers nie uit hul eie van hulle (godgelegitimeerde) mag sal afstand doen nie, bly onbeantwoord. Soos oorlog word revolusie as allerlaaste uitweg beskou (p217). Revolusie (van onder) word egter nie goedgekeur soos oorlog (van bo) nie. Baie duidelik word hier wel gevra vir 'n hand-in-eie-boesem-steek-houding: "Alles sal gedoen moet word om 'n vrugbare teelaarde vir 'n revolusionêre groep te voorkom".

\subsection{Oorlog as gestalte van gewelddadige protes}

Volgens Heyns is die oorlogvraagstuk waarskynlik die grootste vraagstuk en een van die moeilikste etiese vraagstukke vir die Christendom. Die gedagte wat Heyns hier ontwikkel is myns insiens die beste in sy staatsetiek omdat hy die totale andersheid van moderne oorlogvoering volledig erken en nie biblisisties redeneer nie. Hedendaagse oorlogvoering met kernwapens is onvergelykbaar met Bybelse gegewens en onaanvaarbaar in die lig van die Bybelse boodskap. Die klassieke teologiese skema van regverdige en onregverdige oorlogvoering is nie meer geldig nie en Heyns vra selfs of dit nie God se (voorsienige) wyse is om mense te dwing om oorloë te staak nie (p237). Heyns pleit vir ontwapeningsooreenkomste en 'n belangrike motief in die sosiale etiek, naamlik gemeenskaplike belange van konflikpartye, kom nou op 'n terloopse wyse na vore. Heyns verbind dit nie met sy Voorsienigheidswoordteologie nie, maar brei wel fenomenologies uit op die gemeenskaplike vrees vir oorlog. Dit sal mense hopelik weerhou om kernwapens te gebruik, 'n negatiewe vredestilstand meebring en die geleentheid bied om 'n Bybelse vredesetiek uit te leef (p239).

Dit is jammer dat Heyns nie sy hoofstuk oor Staatsetiek met konkrete norme afrond deur te wys op die staat en ook die internasionale gemeenskap se taak om 'n kultuur van verdraagsaamheid te skep nie. In die huidige tydsgewrig word al sulke pogings deur talle Christene beskou as 'n inherente deel van die sogenaamde New Age bedreiging en word die baba saam met die badwater uitgegooi.

In die riglyne vir 'n vredeskultuur behoort die Bybelse oorlogstekste verantwoordelik geteologiseer te word. Wat is byvoorbeeld die verband tussen individuele en kolletiewe verantwoordelikhede (p226, 227)? Die vredesprofesieë vanuit die Ou Testament behoort nie gemaklik tot die wederkoms verskuif te word nie (vgl Heyns p225). Die eskatologiese eindtyd (sedert Christus se koms) is vol spanning en kreatiewe teenstellinge wat vrugbaar met Heyns se Voorsienigheidsteologie verbind kan word. God werk immers deur en in menslike belange op 'n ondeursigtige wyse om die aarde te bewaar. Slawerny is byvoorbeeld uitgewerk vanweë die industriële-eienaars se dringende behoefte aan 'n meer produktiewe arbeidsreëling en dit is moreel verdedig en deurgevoer met Christelike motiewe. Daar is egter geen Nuwe-Testamentiese teks wat direk sê dat slawerny sonde is nie of dat dit 'n reëling is wat sal ophou voor die wederkoms nie. Tog aanvaar almal 
God se voorsienigheid in die staking van die gebruik. Behoort 'n wêreldkultuur sonder oorlog nie eksplisiet tot die vredestaak van die kerk nie?

Ten slotte oor die "Staatsverband"

Die realiteit dat ons nog nooit ' $n$ ideale staat gehad het wat sy goddelike roeping getrou uitgevoer het nie, word myns insiens nie genoeg verdiskonteer nie. In die Suid-Afrikaanse owerheid het die hoogste ampsdraers openlik hulle Christenskap erken, was daar gereeld en op verskeie wyses noue kontak en selfs ooreenstemming met kerkleiers, is agnostici en ateïste nie toegelaat om weermagoffisiere te word nie. Tog is daar wandade gepleeg, wat meer aan Openbaring 13 se magswellus as aan Romeine 13 se "kwaaddoeners straf" en "goeddoeners beloon", herinner.

Om hierdie en ander redes is dit ' $\mathrm{n}$ waarskynlikheid dat die meerderheid van die mense in die land ten spyte van hulle lidmaatskap aan 'n kerk teen ons wense in vir 'n eksplisiete sekulêre staatshuishouding sal kies. Dit lyk my dat ons nie genoegsaam toegerus is om dan die enorme sosiaal-etiese probleme byvoorbeeld ten opsigte van Sondagheiliging, skoolopvoeding, mediadekking, sensuur, te hanteer nie.

Eienaardig genoeg sal juis Romeine 13 ons hierin kan help. Christene moet die sekulêre staat eerbiedig soos die heidenstaat in Paulus se tyd. Soos slawe vir hul base moes werk asof vir die Here, moet Christene se gehoorsaamheid aan die staat wees asof vir die Here self. Hulle aktiewe bydrae moet gekenmerk word deur die liefde (vgl Rom 12 en Rom 13:8 ev wat Rom 13:1-7 omsluit).

Ek sou wou voorstel dat die Christen se aktiewe liefdesbetrokkenheid by die samelewing en die sekulêre staat vanuit 'n alternatiewe denkstruktuur beskou moet word. Die klem is nie op die staat as 'n amp van die koninkryk nie, maar op die Christene wat die koninkrykseise dienend (en nie voorskrywend nie) in die staat indra.

Hierdie betrokkenheid by die wêreld geskied myns insiens op verskillende vlakke, en die aansluitings- of verwysingspunt is nie die Koninkryk van God nie, maar wel verskillende koninkrykseise. Op 'n eerste vlak of in terme van 'n binnesirkel is Christene betrokke by hul eie geloofstradisie en ekumeniese familie. In 'n volgende sirkel is Christene betrokke by mede-landsburgers op grond van hulle gemeenskaplike nasie-burgerskap en landsbodem. In 'n derde sirkel is Christene betrokke by ander mense van ander gelowe. Hier is die verwysingspunt die erkenning van die transendente werklikheid. Die volgende vlak of vierde sirkel se gemeenskaplike verwysingspunt is gemeenskaplike menslikheid en lewe. Op die vlak moet Christene (met koninkryksperspektiewe) betrokke wees om lewe in die algemeen en in die besonder menselewe op alle wyses te bevorder. Blyke van hierdie vierde vlak word wel by Heyns se behandeling van konsultasie in SuidAfrika "op grond van humaniteit" en "met die oog op die bevordering van humaniteit" gevind (p72).

4. "Kerkverband" - 'n idealistiese vennootskap of eerder realistiese diensknegskap?

In die slothoofstuk (hoofstuk 11) behandel Heyns die uniekheid van die kerk (die "wese van die kerk"), die handelinge in die kerk ("intrakerklike sosiaal-etiese lewe"), 
die handeling van die kerk na buite ("interkerklike sosiaal-etiese verhoudinge"), die verhoudinge van die kerk ("ekstrakerklike sosiaal-etiese verantwoordelikhede") en die bedreiginge vir die kerk van binne en buite ("antikerklike sosiaal-etiese bedreiginge").

Die kerk is vir Heyns 'n nuwe gemeenskap van mense op grond van God se heilswerk en nie op grond van natuurlike solidariteit nie. As nuwe gemeenskap moet dit 'n terapeutiese model wees vir die samelewing - 'n "alternatiewe gemeenskap" (p298-299). Die ekumeniese ingesteldheid van kerkinstitute word onderstreep en ten opsigte van die sendinggerigtheid word die bekende onderskeid (oorspronklik van Gensichen) tussen sendingdimensie en sendingintensie gehandhaaf en sending word nie tot die "siel" of tot die "sondige struktuur" gereduseer nie.

Wat betref die kerk se verhouding tot die wêreld vat die skrywer dit saam in sy bekende dialektiek van "kritiese solidariteit" (p319). Die kerk ken geen "terreinbeperking" nie, maar "taakbeperking" (p326, 333). Gevolglik word Artikel 21 van die Ned Geref Kerkorde - "kerklike sake op kerklike wyse" - prinsipieel betwyfel en daar word voorgestel dat dit sal lui: "Alles wat die vergadering in behandeling neem, word op kerklike wyse hanteer".

Voorstanders van gemeentebou sal ook bly wees dat Heyns organisasievorme as tydgebonde beskou en dat dit moet verander ten einde begrypende kommunikasie te bewerkstellig (p321). Elders word die "institusionalistiese verwording van die kerk", met ander woorde die oordrewe kerkordelikheid, as een van die bedreiginge van die kerk van binne beskou wat die gemeenskap van die gelowiges verswak $(\mathrm{p} 382,383)$.

Ten opsigte van die verhouding kerk en volk neem Heyns die filosofiese onderskeiding tussen wêreldkerk ("een groot broederskap") en volkskerk (soos vroeër by Duitse sendingwetenskap en Nederlandse Hervormde Kerk) as negatiewe uitgangspunte. Van die "wêreldkerk" word geen voorbeeld of voorstander genoem nie en dit word nie teen die klassieke kerkeienskappe van "algemeenheid" (katolisiteit) en eenheid afgegrens nie.

Op positiewe wyse wil Heyns sowel die etniese solidariteit as die etniese transendensie van die kerk handhaaf. Die solidariteit word gegrond op die eise van inkarnasie of verinheemsing wat myns insiens op die punt neig om verskraal te word tot kommunikatiewe eise: "Die diepste teologiese motivering vir die band met die volk, vir oornames uit die volkslewe en vir die gebruik van volkstaal en selfs vir die konstituering van taalkerke, is die eis dat die groot dade van God goed verstaanbaar sal wees, en dat dit die gemeenskap van die gelowiges sal stimuleer" (p330).

Die liggaam van Christus transendeer egter ook historiese groepvorming, is en bly vry van eksklusief etniese-kulturele gebondenheid en is gehoorsaam aan die eise van die Woord, waaronder die versoeningseis om volke te "verbroeder", maar nie te "vermeng" of hul "afsonderlike naasbestaan te verleng nie" (p332). Heyns handhaaf dat "afsonderlike kerke vir afsonderlike bevolkingsgroepe nie in beginsel verkeerd is nie, mits ook aan die eenheid van die kerk konkreet-sigbare uitdrukking gegee word", maar vervang dit met wat hy noem 'n beter formulering. Myns insiens is dit meer as net 'n nuwe formulering: "Die een kerk kan in hom 'n verskeidenheid etnies-kultureel bepaalde bedieningspatrone verenig" (p331). Dit is in geheel jammer dat Heyns nie meer by etiese konkretisering van hierdie transkulturele intrakerklike persoonsbehartiging uitkom nie, aangesien die potensiële verrykende ontmoeting uitdagende maar moeilike sosiaal-etiese dilemmas in die 
gemeentepraktyk het.

Ten opsigte van kerk en politiek waarsku Heyns enersyds tereg teen 'n verpolitisering van die ganse samelewing en die kerk (as instituut) by name. Andersyds is die kerklike en politieke "terreine" nie geskei nie en beteken die kerk se "politieke taak" onder andere voorbidding, verkondiging en voorbereiding van die jeug vir "alle menslike aktiwiteite". Heyns raak hier ten opsigte van die kategese en pastoraat meer konkreet. Terwyl Heyns tereg daarop wys dat "blote kennis van die belydenisskrifte is nie voldoende vir die uitdagings wat die moderne lewe bied nie" (p346), is dit 'n probleem in hoeverre 'n Skriftuurlik-maatskaplike riglyn net verkondig moet word en nie in meer konkrete norme omgesit moet word nie (p342343). Op nog 'n ander wyse stel Heyns dat die volle implikasies van die boodskap oor die koninkryk van God deur die kerk met moderne woorde en begrippe verduidelik moet word vanweë die historiese bepaaldheid van die Skrif (p350-361). Die hermeneutiese probleem bly dat selfs die beginsels nie so maklik "onthistoriseer" kan word nie.

\section{Ten slotte}

As ek ten slotte een saak in die besonder kan noem, is dit die Voorsienigheidswoord. Myns insiens is Heyns se sterkste argument ook sy swakste. Die Voorsieningheidswoord is ' $n$ Gereformeerde uitweg vir kontingente normering, aangesien dit 'n dialektiese beweging tussen die deduktiewe en induktiewe wyses van teologisering kan laat plaasvind. Dit het die potensiaal om 'n selfkritiese instrument te word waarmee die bostruktuur van beginsels getoets kan word of dit in werklikheid nie alreeds net bepaalde magsbelange verteenwoordig nie. Tog gebeur dit nie by Heyns nie omdat die Voorsienigheidswoord soms op 'n subjektivistiese wyse funksioneer. As dit byvoorbeeld aan die ekumene verbind sou word kan hierdie inherente gevaar - waaraan alle etisering onderworpe is - verminder word.

Om in die Christelike sosiale etiek toegerus te word is ' $n$ omvattende onderneming. ' $n$ Mens se gedagtes moet gegrond wees op die Skrif en daarom is insig in die bibliologiese vakke noodsaaklik. 'n Mens moet egter ook die hedendaagse denkpatrone en problematiek in die lig van Gods Woord verstaan, wat 'n kennis van die dogmatiek en basiese informasie van verskeie vakwetenskappe behels. Die geloof in die Here God en die situasie waarin ons leef moet verder in verband gebring word sodat die praktiese vakke dit kan neem om dit in die prediking, kategese, sendinggetuienis en pastoraat te kommunikeer. In hierdie uiters moeilike en omvattende taak help Heyns se trilogie. Indien sekere probleemareas bygewerk word, sal dit studente en predikante in staat stel om vanuit 'n behoorlike etiese denkraamwerk 'n geloofwaardige bydrae tot die sosiaal-etiese problematiek van ons tyd te kan lewer.

\section{NOTAS:}

1 In die verband herinner Heyns aan James Gustafson, Ethics from a Theocentric perspective, Chicago 1981, wat argumenteer dat geldige onderskeidings alleen teosentries (en nie outonoom nie) gedoen kan word. Heyns se Bybelse godsbegrip verskil egter drasties van Gustafson se 
verontpersoonlike godsbeskouing.

2 In Jürgen Moltmann se Gerechtigheid schept toekoms: Vredespolitiek en scheppingsetiek in een bedreigde werreld, Baarn 1990, word die ideaal van 'n messiaanse etiek universeel begrond. Die ideaal van geregtigheid is nie eksklusief vir Christene nie, maar inklusief vir alle mense. Dit is gebaseer op die eerbiediging van die belange van almal.

3 C S McCoy se When Gods change: Hope for theology, Nashville 1980, en L Gilkey se Society and the sacred: Towards a theology of culture in decline, New York 1981, is werke waarin die skrywers hul eie denkparadigmas en tradisies doelbewus toets. In K Nurnberger, Power and beliefs in South Africa: Economy potency structures in South Africa and their interaction with patterns of conviction in the light of a Christian ethic, Unisa 1988, se sisteemanalitiese teorie toon hy aan hoe belange 'n vername entiteit is wat tussen magstrukture en etiese ideale funksioneer.

4 Om 'n boek te kritiseer vir wat nie daarin geskryf staan nie, mag op die oog af na misplaaste kritiek lyk. My doel is egter om te probeer vasstel tot watter mate Heyns se Etiek ons sal kan help om verantwoordelike etiese besluite te neem. Leemtes is dus wel ter sake. Laat ek egter onmiddellik byvoeg dat die inhoud van die hoofstukke, die uitgebreide endnotas (95 bladsye teenoor 310 bladsye van die hoofstukke), en die literatuurlys Heyns se formidabele leeskennis en oorsig oor sy vak bewys en toon dat hy baie moeite doen om sy lesers in die skatte te laat deel.

5 In die Gereformeerde skrywer W Banning se klein boekie Inleiding tot die sociale ethiek, Wassenaar 1975, is ekonomiese en produksieprobleme van die van die grootste belang. Die val van die kommuniste het nie getoon dat die materiële denke oorskat is nie, maar het juis bevestig dat materiële faktore die ideële faktore (al is dit dan ook oor die materiële) kan oorskadu. In sy nuwe ensikliek, Centesimus Annus, wat op die 100 -jarige herdenking van Rerum Novarum vrygestel is, waarsku Pous Johannes Paulus II, wat bekend is vir sy stryd teen die kommuniste, dat ons na die kommunistiese ineenstorting in Oos-Europa nie die kapitalistiese sisteem as evangelie moet aanvaar nie (Kerklijke Documentatie, 19(3) [Mei 1991]).

6 E Brunner, Das Gebot und die Ordnungen, Zurich 1939.

7 D Bonhoeffer, Ethik, Munich 1949.

8 G Winter het vir sy bevrydingsetiek Gadamar en Ricoeur se insigte oor metafore as grondslag van die samelewing benut in Liberating Creation: Foundations of Religious Social Ethics, New York 1981. Daarmee wil ek geensins voorspraak doen vir 'n Bevrydingsteologie se etiek nie. Inteendeel, ons behoort toegerus te word om ons op sinvolle wyse teen sodanige teologie te kan verdedig. 